Kapliyenko-lliuk Yuliya

$\mathrm{PhD}$ in Arts, associate professor, doctoral student of the Odessa National

A. V. Nezhdanova Academy of Music ORCID 0000-0002-6114-9680 yuliyakaplienko@gmail.com

\title{
"WANDERING STARS" BY LEONID ZATULOVSKYI: TRADITIONS AND INNOVATION IN THE INTERPRETATION OF THE SYMPHONIC SUITE GENRE
}

The purpose of the article is to identify the peculiarities of the genre made on the basis of the analysis of the symphonic suite by L. Zatulovskyi and to characterize the features of the works of the Bukovynian composer. Methodology. The methods of historical-cultural, theoretical and genre-style analysis were used, which allowed to reveal traditional and innovative techniques of interpretation of the genre of the symphonic suite. The scientific novelty consists in understanding the development process of the professional musical art of Bukovyna; in revealing features of creative thinking of the composers of the region; in clarifying the principles of orchestral music of the region; in the analysis of music by L. Zatulovskyi, whose work was not explored in contemporary musicology. Conclusions. The orchestral suite "Wandering Stars" concentrates the signs of creative thinking of L. Zatulovskyi, his principles of work, which combine the properties of various fields of music, thereby denoting the formation of polystylistics, where the classical traditions of European and Ukrainian music, folk music creative work and traits of Bukovynian multinational musical culture are interwoven. L. Zatulovskyi's suite is an example of the scene-genre programme symphonism, where the background of the colourful national environment reveals the relationship between the heroes of the novel by Sholem Aleichem. On the basis of this work by L. Zatulovskyi one can identify the features of his individual creative style. The composer, relying on genre features of folk music, was able to achieve his own originality of writing. L. Zatulovskyi, intertwining the intonation and rhythmic features of the Ukrainian, Bukovynian and Jewish song and dance traditions, enriched the melody of his works and brought it to a new level of interaction with harmony and a tone-key component.

Key words: genre; symphonic suite; programme music; composers of Bukovyna; Leonid Zatulovskyi.

Каплієнко-Ілюк Юлія Володимирівна, кандидат мистецтвознавства, доцент, докторант Одеської національної музичної академії ім. А. В. Нежданової чної сюїти

"Блукаючі зірки" Леоніда Затуловського: традиції та новаторство в інтерпретації жанру симфоні-

Мета статті - на основі аналізу симфонічної сюїти Л. Затуловського виявити особливості жанру та охарактеризувати риси творчості буковинського композитора. Методологія. Застосовано методи історикокультурологічного, теоретичного та жанрово-стильового аналізу, що дозволило виявити традиційні та новаторські прийоми інтерпретації жанру симфонічної сюїти. Наукова новизна полягає в осмисленні процесу розвитку професійного музичного мистецтва Буковини; у виявленні рис творчого мислення композиторів краю; у з'ясуванні засад оркестрової музики регіону; в аналізі музики Л. Затуловського, творчість якого не досліджувалась у сучасному музикознавстві. Висновки. Оркестрова сюїта "Блукаючі зірки" концентрує ознаки творчого мислення Л. Затуловського, його принципи роботи, у яких поєднано властивості різних напрямів музики, що вказує на утворення полістилістики, де переплелися класичні традиції європейської та української музики, народна музична творчість та риси буковинської багатонаціональної музичної культури. Сюїта Л. Затуловського - зразок картинно-жанрового програмного симфонізму, де на фоні колоритного народного середовища розкриваються стосунки героїв роману Шолом-Алейхема. На основі даного твору Л. Затуловського можна виявити риси його індивідуального творчого стилю. Композитор, спираючись на жанрові ознаки народної музики, зміг досягнути власної оригінальності почерку. Переплітаючи інтонаційні та ритмічні прикмети української, буковинської та єврейської пісенно-танцювальної традиції, Л. Затуловський збагатив мелодику своїх творів та вивів ії̈ на новий рівень взаємодії з гармонією, тонально-ладовою складовою.

Ключові слова: жанр; симфонічна сюїта; програмна музика; композитори Буковини; Леонід Затуловський.

Каплиенко-Илюк Юлия Владимировна, кандидат искусствоведения, доцент, докторант Одесской национальной музыкальной академии им. А. В. Неждановой

"Блуждающие звезды" Леонида Затуловского: традиции и новаторство в интерпретации жанра симфонической сюиты

Цель статьи - на основе анализа симфонической сюиты Л. Затуловского выявить особенности жанра и охарактеризовать черты творчества буковинского композитора. Методология. Применены методы историкокультурологического, теоретического и жанрово-стилевого анализа, что позволило выявить традиционные и новаторские приемы интерпретации жанра симфонической сюиты. Научная новизна заключается в осмыслении процесса развития профессионального музыкального искусства Буковины; в выявлении особенностей творческого мышления композиторов края; в выяснении основ оркестровой музыки региона; в анализе музыки Л. Затуловского, творчество которого не исследовалось в современном музыковедении. Выводы. Оркестровая сюита "Блуждающие звезды" концентрирует признаки творческого мышления Л. Затуловского, его принципы работы, в которых сочетаются свойства различных направлений музыки, что указывает на образование полистилистики, где переплелись классические традиции европейской и украинской музыки, народное музыкальное творчество и черты буковинской многонациональной музыкальной культуры. Сюита Л. Затуловского - образец

(c) Kapliyenko-lliuk Yu., 2018 
картинно-жанрового программного симфонизма, где на фоне колоритной народной среды раскрываются отношения героев романа Шолом-Алейхема. На основе данного произведения Л. Затуловского можно выявить черты его индивидуального творческого стиля. Композитор, опираясь на жанровые признаки народной музыки, смог достичь своей оригинальности почерка. Переплетая интонационные и ритмические приметы украинской, буковинской и еврейской песенно-танцевальной традиции, Л. Затуловский обогатил мелодику своих произведений и вывел ее на новый уровень взаимодействия с гармонией, тонально-ладовой составляющей. Затуловский.

Ключевые слова: жанр; симфоническая сюита; программная музыка; композиторы Буковины; Леонид

Relevance of the research topic. Leonid Borysovych Zatulovskyi is one of the representatives of modern composer school, who in his creative work combines a high level of professionalism, talent with the ability to be modern and in demand. His music is very popular both among professional Ukrainian artists and performers, as well as among the younger generation of musicians. His works, in particular orchestral music, sound on prestigious scenes of Ukraine and abroad performed by well-known bands. L. Zatulovskyi developed his own style, which is characterized by a solid alliance of Western European and Ukrainian professional traditions, folk instrumental and song creative works, Bukovynian and Jewish colour, modern popular music and jazz. But most of all, as the composer noticed, he admires Ukrainian folk song, love for which he carried through all his life [7].

Analysis of recent research and publications. Composers' activity and peculiarities of development of various branches of creative work of modern representatives of musical art of Bukovyna are almost investigated. The existing textbooks on history of music consider the development of musical culture in Bukovyna in the context of the general characteristics of West-Ukrainian music. In the modern scientific space there are several publications devoted to the historical past of Bukovyna, among which there are two works of historical-journalistic character by K. Demochko [4;5]. A more detailed and informative source about the history of musical culture and education of Bukovina remains the collective work of the scientists of the Department of Music of Y. Fedkovych Chernivtsi National University [8]. L. Zatulovskyi's creative work has never been the subject of musicological analysis. There are many publications in the periodical press and reference books about his creative life and performing activities $[1 ; 3 ; 6 ; 10 ; 14]$, in separate sections of the manuals, in particular in the educational edition of "Bukovynian Composers" [2]. However, these studies do not dwell on the style of composers of Bukovyna, and the creative work of L. Zatulovskyi is not investigated.

The purpose of the research is to analyse the symphonic suite of $L$. Zatulovskyi and, on the basis of the analysis, to identify the peculiarities of the genre and characterize the features of the creative work of the Bukovynian composer.

Research findings. The scope of creative work of L. Zatulovskyi is represented by various branches of composer work, in particular, works for symphonic, chamber, wind, pop orchestra and orchestra of folk instruments, chamber-instrumental works for piano, accordion, string, wind and folk instruments, concerts for piano and violin with orchestra, vocal works and music for children, arrangement. Most of his works exist in the author's originals and manuscripts, which need to be ordered and published. Therefore, modern scholars face an extremely urgent task connected with the musical assessment of his legacy and the well-grounded popularization of the achievements of the Bukovynian composer.

Among the large number of musical productions by L. Zatulovskyi, we select his monumental works meant for the orchestra. He is the author of 6 "Bukovynian Rhapsodies", a suite "Wandering Stars", which exist for various composition of orchestras (symphonic, chamber, wind), a symphonic poem "Bukovyna", a cantata "Memory" for soloists, choir and symphony orchestra and separate pieces.

Orchestral thinking of the composer is distinguished by a combination of peculiar academism with peculiarities of folk music, song and dance tradition. Academic principles are connected, first of all, with the genre priorities that are characteristic of Ukrainian music of the second half of the XXth century. The first orchestral opuses of the composer coincide with the time of the creation of iconic works of Ukrainian professional symphonic creativity, which, based on the achievements that were formed at the beginning of the century in the works of S. Lyudkevych, P. Kozytskyi, A. Shtogarenko, G. Mayboroda, K. Dankevych, V. Barvinskyi, M. Verykivskyi, M. Kolessa and others, are demonstrating the search for new ways of developing orchestral music. In this context, the $60 \mathrm{~s}$ - the beginning of the $70 \mathrm{~s}$ are marked by special experimentation in the field of symphonic music, which led to the appearance of works that, according to B. Syuta, "became remarkable achievements of both domestic and, more broadly - European music" [13, 505]. During this period, many orchestral works were created in various genres, which reflected the desire of composers to experiment, to show non-standard thinking, to update the existing forms with new qualitative transformations. The so-called genre of the programme symphonic suite, which appeared in European music in the second half of the XIXth century, was developing and became closer to the genre of the "plot-dramatic symphony" [11, 184]. In the work of L. Zatulovskyi, the genre of the orchestral program suite is clearly presented by the work "Wandering Stars", which became the "visiting card" of the composer and sounded not only on Ukrainian stages, but also at the New York Philharmonic Society [14].

The suite "Wandering Stars", consisting of five contrasting parts, independent and bright folkcharacteristic scenes ("Road", "Star Steppe", "Dance", "Lullaby", "Holiday"), is inspired by the images of Sholem Aleichem's novel of the same name. This cycle is characterized by a combination of lyrical, genre and 
scene-pictorial plays, following the paths that $\mathrm{R}$. Schumann has already identified in his cycles of piano miniatures. In Ukrainian music, one of the first works in the genre of orchestral suite - "Vesnyanky" by M. Verykivskyi, demonstrates the principles of assimilation of folk-song sources [12, 45]. Along with the works of this genre focused on the song symphonism, which was manifested in the works of $V$. Sokalskyi ("The Take-off of Slavic Falcons"), V. Oholovets ("Ukrainian Suite"), D. Akhsharumov ("Suite on Ukrainian Themes in the Style of Ancient Music ") and others, since the beginning of the 1950s there were suites whose programme character was associated with well-known personalities ("In Memory of Lesya Ukrainka" by A. Shtogarenko, "Taras Shevchenko" by B. Lyatoshynsky). The literary programme was not quite widespread among the works that were at the root of the development of genres of Ukrainian orchestral music. It was only in 1925 that the first programme suite "Kozak Golota" by P. Kozytsky emerged on the basis of music to F. Lopatinsky's performance of the same name. In 1955, B. Lyatoshynskyi turned to the dramatic images of W. Shakespeare and created a suite "Romeo and Juliet". Since the 1960s, Ukrainian composers often turn to the genre of an orchestra suite, first creating suites based on music from movies and theatrical performances. However, gradually this genre gained independence and became the basis of the works of B. Lyatoshynskyi, M. Dremlyuga, V. Guba, L. Kolodub, L. Dychko, A. Karamanov, L. Grabovsky [13, 505].

Thus, the traditions initiated by the Ukrainian composers of the first and the beginning of the second half of the twentieth century, influenced the nature of the works of contemporary composers, determined the ways of developing the genres of orchestral music. Creative work of Bukovynian composers rapidly joined the flow of development national music, but, unfortunately it remained in the shadows, and did not become the object of musicologists' study and analysis. Thus, the orchestral music of L. Zatulovskyi, entering concert programmes along with the works of famous Ukrainian composers of the second half of the 20th - the beginning of the 21st century, deserves the attention of scholars and has the prospect of becoming a textbook.

The author of the suite "Wandering Stars" creates a five-part cycle of individual orchestral plays, which, by means of the genre definition of parts, reveal the relative plot programme character. The images of the heroes of the novel in love are mostly hidden, but the situational element, images of nature and the surrounding world are emerging on the foreground. However, the composer is mostly interested in the nationalcultural basis, connected with folk-household and family-household folklore. L. Zatulovskyi deliberately fails to cite, but the entire work is permeated with signs of folk art of the multinational Bukovyna region.

The first part of the suite - "The Road" - is a play of pictorial-scenic programme character, drawing pictures of the journey of the Jewish travelling theatre, with which the sweethearts Rasel and Label escape from their hometowns in their dreams of happy future and successful stage career. To implement his idea, the composer chooses a verse-variational form, where two relatively contrasting sections, performing the functions of introducing the tune and chorus, are repeated with variational changes. The principle of variation permeates the form both from the outside and from the inside. Frequent repetitions of the main thematic sections are modified by the melodic, rhythmic, texture, tone and structural variations, and create the impression of a continuous monotonous movement of the travelling carriage with the artists. On the other hand, the structure of the composition resembles the features of a double simple two-part form with a coda.

The first section of the form begins with a small four-time introduction of a monotonous character with a typically popular simplified style with alternating bass and chord resembling the accompaniment of a song. A harmonic plan for the original element was originally solved, where polychord couplings were applied, in which the tonic tri-sound is laid upon the sounds of a dominant and an introductory tone. However, their alternate appearance hides the dissonance that could arise with the simultaneous sounding of the functions, and even creates a sound-imaging moment of rocking a carriage. On the background of pizzicato strings there appears a song, a vividly national Jewish melody in trumpet with damper in the B flat major with peculiar fret alterations of the second, sixth and seventh lower degrees. The variability of the seventh degree of the fret adds a folk colour, reproduces the fret signs of Jewish music with typical enlarged seconds. The initial element of the theme, being its core, is constantly repeated with variations of the melody and rhythm, shifts from one instrument to another. Such techniques characterize the periodic repetition of scale-thematic structures and are a sign of everyday genres. The melodic mediant duplication reproduces the character of folk ensemble singing.

The second section is written in the same name in the B flat minor, but the character continues the mood of the previous part. If the first section-verse reflects mainly solo singing, the second one performs the function of a solemn collective chorus. The theme is polystylistic, where the signs of Jewish and Ukrainian singing are combined. Despite the rather well-developed periodic constructions, their structure is closely connected with frequent, though variational repetitions. This method further emphasizes the composer's plan to convey the long and monotonous way of artists travelling from town to town. Before the appearance of the next section, there is a short two-time connective element, which, with ascending octaves of violins with displaced metric accents, originally depicts the creaking of the carriage wheels, and, at some point, even resembles the whipping of the lash, which drives the horses. Taking advantage of the thoughtful drama of development, L. Zatulovskyi was able to convey vividly folk images, characteristic singing and reproduce the atmosphere of a long way with its colourful participant -the carriage.

The second part of the suite - "Star Steppe" - is a slow lyrical musical scene, where two lyrical heroes are presented against the background of the steppe landscape and the starry sky. The landscape is 
reproduced by various colouring means, which combine the signs of folk melody, richness of fret, style contrasts and sonorous consonance. The beauty of nature, the breadth of space and vivid picturesque character resemble the typical images of "Shahrazad" by M. Rimsky-Korsakov. The composition of "Star Steppe" is performed in an intermediate form between a complex and a simple three-part one, where the extreme sections are written in the form of a period, and the middle - in a simple three-part form with complex periods.

Consequently, the first section of the form - the colouring content, where the harmonious means and spectacular mediant parallelism represent the starry sky, which is fascinating and inspiring. The period consists of two contrasting sentences (8 and 6 times), where the first shows a background theme, in which, due to a sonorous sound, altered chords, signs of major-minor of the same name and passage harp bursts, the colourfulness comes to the fore.

The main theme of the first section contains three contrasting elements, where the first one, with its soft song turns in twice the harmonic minor, is intonationally associated with the theme of the first part of the suite, indicating the signs of a monotheme. The second element, formed from three eighths of the half-time and half duration with a characteristic sixth romance intonation, will play a significant role in the development of the form. Splashes of the harp, which, like starlight, appearing in the first section of the form, became the basis of the third element of the theme. The last two formations are symbols of the images of the heroes of the novel, characterized by the contrast of the performance and the tone.

The middle section of a simple form of developmental character, is based on the development of the first two elements of the theme. The development completes with a five-step climax, where a new episodic theme invades on the $f f$ in the copper wind, symbolizing the highest emotional state. The reprise of the middle is shortened, but dynamised: the tone correlation of the sentences reflect the features of the development, the last sentence - a more detailed one, where the first and second elements of the main theme are contrasted, the passage bursts capture a group of the wooden wind. The tension, which does not disappear in the development of a simple form, has a continuation in the reprise, which rapidly moves into a general varied reprise of the form. Colouring "rockings" go to violins, and the lyrical romance theme of the hero, continuing its intonational transformation, commenced as far as in the development, is becoming a climax. Thus, L. Zatulovskyi, in the "Star Steppe" from the suite "Wandering Stars", was able to achieve an interesting combination of external and internal worlds, images of nature and personal experiences, creating a sample of scene and lyrical symphonism.

"Dance" is the third part of the cycle in which the composer has shown his ability to deepen into the field of folk dance, dance and cheerful euphoria. The work is written in the form of double variations with an introduction, where two themes sound alternately, and variations appear on the principle of alternating interchange. The introduction of a figurative nature, without its own theme, reproduces the sound of the folk orchestra of triple musicians. It consists of three small sections, the last two of which are variants of the first one, which "predicts" the future variation development. The two themes of the main part of the work are related by the general dance mood and tone. The first theme continues the nature of the introduction and is based on two thematic elements alternating and repeated in different groups of the orchestra. The dominant harmony, completely accompanying the melody, has a logical end with the beginning of the second, song theme. The methods of variation used by L. Zatulovskyi in the "Tank" are rather concise, simple and closely related to the principles of folk music, where the varied structures appeared spontaneously and did not differ in complexity. The main idea of the dancers is connected with the creation of the appropriate mood, which captivated all the participants of the action. Therefore, the laconicism of the means of creating the character of the dance, the principles of development correspond to the genre basis of the work, contributing to its natural perfection and authenticity of the manner.

The fourth part of the suite - "Lullaby" - is a lyrical-sorrowful detachment from the general programme character, where the features of the genre are veiled, and the romantic relationship of the heroes comes to the fore. The character, content and means of embodiment of the images reveal the signs of polystylistics, where the mood of sensitive romanticism and lyricism of P. Tchaikovsky and contemporary music and cinema art are felt, as well as some of the newest chord sounds and features of the national Jewish melody.

"Lullaby" is written in a complicated three-part form with an introduction and a coda. A short five-act introduction in $\mathrm{C}$ minor is based on a comparison of the tonic septochord of a natural minor and a leading double dominant. The sounds of these two chords form a scale that corresponds to the Hutsul fret and brings the folk Bukovynian colour. The broad, chanting theme, entrusted to the cello solo, carries bright features of folk Jewish music, where the presence of chromatism, enlarged seconds, and the emphasis on metric accents by grace notes add authenticity. Attention is drawn to the parallelism of the chords at the end of the first sentence: the fourth consonance and octaves, filled with a fifth, create a character of mystery, and on the other hand, they add sorrowness and doom. Therefore, these chords become a precursor of parting of the heroes.

The intonational content of the themes is closely linked to the first section from the inside, but the major key (A flat major), the absence of sharp nagging enlarged seconds, the softer "lulling" melodic turns form clear, light images and most closely correspond to the genre of a lullaby. The reprise is not ordinary, it is rather thematic, because, like a pseudo-reprise, it is outlined in the secondary F minor key. The coda of 
the "Lullaby" became logical and thought-out, where the composer completely dilutes the style, leaving only the string group. Starting the theme of the first section, as in the beginning, in the solo sound of the cello, the melody is transmitted to the violin solo, which goes into a gentle, upward improvisation, freezing on a keynote of $\mathrm{F}$ minor.

"Holiday" - the final part of the suite, where the principle of kaleidoscopicity combined several contrasting genre and dance scenes into one form. As a result, a fairly free composition was formed, which, in its structure, resembles a contrast-composed form with an end-to-end development of the initial theme of the introduction. Folk dances, which constantly change each other, correspond to the traditions of "knitting" songs, that were widely spread in Ukrainian music. The solemnly elegant finale of the suite begins with the fanfare theme of the introduction in the G major, where the strokes of the tonic tri-sound of the tutti orchestra alternate with the sounding of string and copper wind instruments, thus preparing for the beginning of the national holiday. For the first section of the form the composer chooses the composition of the brass band, instructing it to perform the march, the character of which introduces the street folk festival. Solo-minor march is lively and brilliant, full of perseverance and enthusiasm, despite its minor key.

The second section is based on the counterpoint of two contrasting themes - the song, performed by violins, and the scherzo-dance, which sounds like a clarinet. As a substitute for wooden and string groups, the middle of a simple three-part form is based on a comparison of brass wind with percussion and string groups. Such a contrasting combination reveals a figurative filling of the dance, in which men's confident perseverance is contrasted with feminine ease.

The third section of the form has a waltz genre basis. The initial theme of the waltz is given to the solo trombone and intonationally associated with the thematic material of the "Lullaby". Further development reproduces typical turns from the second part of the suite, resembling the second element of the theme "Star Steppe".

The fourth section is the brightest and most distinctive dance element, where the mood of the national holiday is revealed with the help of genre-typical turns of Bukovynian folklore. The main thematic events of the previous sections of the final part of the suite are described in minor keys ( $G$ minor and $C$ minor), but gradually establish the major key. The element of dance increasingly occupies musical space and develops into a series of individualized thematic constructions. The character of the dance and some intonation turns arouse association with the famous dance Jewish song "Hava Nagila". The fiery melody gradually captures the registers and various tones of the orchestra, demonstrating the collective performing of the festive dance. After a two-time varied conducting of the main thematic link, the composer introduces the first introductory theme, where the unison-fanfare sound prepares the appearance of a contrasting middle. However, the function of this invasion is greater than the introduction: it is a kind of reminiscence and one of the forms of end-to-end development in the form. In the middle there appears a colourful theme in the solo clarinet, which is then picked up by the trumpets, creating a mood of folk festival, where the performers in turn show a skilful play on the instruments. The coda that sounds in $\mathrm{C}$ major, is perceived as a general summing up part of the whole suite. The elevated-patriotic theme is performed by the chord composition in the trumpet part with a gradual increase in the dynamic plan with the participation of all orchestral groups. Consequently, the scene of a national holiday with a contrast of moods and behaviour is skilfully reflected by the composer by means of genre contrasts, colourful instrumentation and the use of intonational sources of folk music.

Conclusions. On the basis of the analysis of the suite "Wandering Stars" by L. Zatulovskyi, we can draw conclusions not only about the peculiarities of the cycle, but also about the features of the style of the composer, manifested in all his creative work. This work accumulates the signs of creative thinking of L. Zatulovskyi, his principles of work, which combine the properties of various fields of music, which points to the formation of poly-stylistics, where the classical traditions of European and Ukrainian music, folk musical creative work and attributes of the Bukovynian multinational musical culture are interwoven.

The suite of $L$. Zatulovskyi is a programme symphonic work of a literary source, where there is a scene, a landscape on the foreground and on their background, there is somewhat hidden, and the relationship of lyrical heroes develops. The principles of kaleidoscope and cinema do not allow to hold on to specific emotions, they create a course of events that are sometimes not interconnected. However, the premonition of the final novel, the parting of the heroes, in spite of the overall positive mood of the suite, is visible in almost all parts: the downward development of the theme dominates and is especially vivid in the "Lullaby" in the form of parallelism of chords.

By various means, in particular with the help of peculiarities of orchestration, L. Zatulovskyi finds accurate sound-imaging techniques, skilfully reproducing the rocking of the carriage or the creaking of its wheels and whipping of the lash. Colourfulness is inherent in many means of expressiveness, where the composer, taking the genre features of folk music as a basis, was able to achieve his own originality of style. L. Zatulovskyi enriched the melody of his works by intertwining the intonational and rhythmic features of Ukrainian, Bukovynian and Jewish songs and dances, and brought it to a new level of interaction with harmony and a tone-key component.

The musical manner of the composer is guided by the basics of the homophonic-harmonic composition, but the elements of polyphony in the form of a counterpoint of the themes become quite distinct. In this contrast, the essential techniques of orchestration are used by the composer both as a means of opposition, 
and as principles of unity. In the first case, one can speak about the contrast of presentation and of polytheme, the antithesis of images and situations, and in another case - about common positions that are especially manifested in association with the people and its traditions. Therefore, a well thought-out orchestration, with its tone description and genre type, contributes to the greater disclosure of the programme character.

Among the principles of the thematic material development L. Zatulovskyi prefers variability that derives from the folk tradition, and variational techniques influence the nature of the correlation between themes in different parts of the cycle. Thus, often patterns of various nature are based on the same intonation models, which leads to unexpected monothematic formations (themes of parts I and II, IV and V) and implementation of the principle of reminiscences, combining the cycle and strengthening the links between the parts. This principle, along with the end-to-end symphonic development, the nature of the proportion of parts and genre content gives the suite also the signs of the sonata-symphonic cycle.

Consequently, the suite "Wandering Stars" presents the creative style of the composer, which reflects his peculiar poly-stylistic thinking, which is based on the knowledge of traditions of West-European and Ukrainian professional music, folk art, national traits and their reproduction in the positions of common features with introduction of authentic originality.

1. Богайчук М. А. Література і мистецтво Буковини в іменах: словник-довідник. Чернівці: Букрек, 2005.

$312 \mathrm{c}$.

2. Буковинські композитори : навч. Посібник / уклад. А. В. Плішка. Чернівці: Чернівецький нац. ун-т, 2011.

$143 \mathrm{c}$.

3. Видатні діячі культури та мистецтв Буковини : бібліографрічний довідник / авт.-укл. : Ю.В. Боганюк та ін. Вип. 1. Чернівці : Книги - XXI, 2010. 312 с.

4. Демочко К. Мистецька Буковина : нариси з минулого. Чернівці : Книги XXI, 2008. 336 с.

5. Демочко К. Музична Буковина : сторінки історії. Київ : Музична Україна, 1990. 136 с.

6. Затуловський Леонід Борисович. Серцем з Буковиною : імена славних сучасників / ред. колегія : Г.К. Галиць та ін. Київ : Світ успіху, 2011. С. 179.

7. Інтерв'ю із Затуловським Л. Б. від 29 квітня 2018 р. ; м. Чернівці. Інтерв'юер : Юлія Каплієнко-Ілюк.

8. Кушніренко А.М., Залуцький О.В., Вишпінська Я.М. Історія музичної культури й освіти Буковини : навч. посібник. Чернівці : Чернівецький нац. ун-т, 2011. 376 с.

9. Маслій М. М. Золотий вік української естради (1960 - 1980-ті роки). Книга 1. Чернівці: Букрек, 2016. $400 \mathrm{c}$.

10. Пам'ятаймо! (Знаменні та пам'ятні дати Буковини в 2010 р.) : бібліограф. показч. / авт.-укл. : Ю.В. Боганюк. О.О. Гаврилюк ; ред. М.М. Довгань. Чернівці : Книги - XXI, 2009. 400 с.

11. Попова Т. Симфонические сюиты второй половины XIX и XX века. Музыкальные жанры / общ. ред. Т.В. Поповой. Москва : Музыка, 1968. С. 184-190.

12. Пясковський І. Б., Шеффрер Т. В. Симфонічна музика. Історія української радянської музики / ред. колегія : О.С. Зінькевич та ін. Київ : Музична Україна, 1990. С. 43-58.

13. Сюта Б. Музичне життя і творчість 1960-х - початку 1970-х років. Корній Л.П., Сюта Б.О. Українська музична культура. Погляд крізь віки : монографрія. Київ : Музична Україна, 2014. С. 498-511.

14. Фещук Н. Його "Блукаючі зірки" звучали в Нью-Йоркській філармонії. Чернівці. 2015. 10 вер. С. 10.

\section{References}

1. Boghajchuk, M. A. (2005). Literature and art of Bukovina in names. Chernivtsi: Bukrek [in Ukrainian].

2. Plishka, A. V. (2011). Bukovinian composers. Chernivtsi: Chernivetskiy nats. un-t [in Ukrainian].

3. Boghanjuk, Ju.V., \& Ghavryljuk, O.O., \& Dobrovoljsjka, Gh.V, \& Dovghanj, M.M., \& Ivanycjka, A.S. (2010). Prominent figures of culture and arts of Bukovina (Vols. 1). Chernivtsi: Knyghy - XXI [in Ukrainian].

4. Demochko, K. (2008). Art Bukovina: essays from the past. Chernivtsi: Knigi XXI [in Ukrainian].

5. Demochko, K. (1990). Musical Bukovina: history pages. Kyiv: Muzichna Ukraina [in Ukrainian].

6. Ghalycj, Gh.K., \& Ghurbyk, B.O., \& Isak, A.F., \& Marusyk, T.V., \& Struk, N.O. (Eds.). (2011 Zatulovsky Leonid Borisovich). The heart with Bukovina: the names of glorious contemporaries, (p. 179). Kyiv: Svit uspikhu [in Ukrainian].

7. Kaplijenko-lljuk, Ju. (2018). Interview with Zatulovsky L. B. Chernivtsi [in Ukrainian].

8. Kushnirenko, A. M., \& Zalucjkyj, O. V., \& Vyshpinsjka, Ja. M. (2011). History of musical culture and education of Bukovina. Chernivtci: Chernivecjkyj nac. un-t [in Ukrainian].

Ukrainian].

9. Maslij, M. M. (2016). The Golden Age of Ukrainian Pop (1960 - 1980s) (Vols.1). Chernivtsi: Bukrek [in

10. Boghanjuk, Ju.V., \& Ghavryljuk, O.O. (2009). Let's remember! (Significant and memorable dates of Bukovina in 2010). M.M. Dovghanj (Ed.). Chernivtsi: Knyghy-XXI [in Ukrainian].

11. Popova, T. (1968). Symphonic suites of the second half of the 19th and 20th centuries. T.V. Popova (Eds.), Musical genres (pp. 184-190). Moscow: Muzyka [in Russian].

12. Pjaskovsjkyj, I.B, \& Sheffer, T.V. (1990 Symphonic music). O.S. Zinjkevych (Eds.), History of Ukrainian Soviet music, (pp. 43-58). Kyiv: Muzychna Ukrajina [in Ukrainian].

13. Sjuta, B. (2014 Musical life and creativity of the 1960s - early 1970s). L.P. Kornij \& B.O. Sjuta. Ukrainian musical culture. A look through the ages: a monograph, (pp. 498-511). Kyiv: Muzychna Ukrajina [in Ukrainian].

an].

14. Feschhuk, N. (2015) His "Wandering Stars" sounded at the New York Philharmonic). Chernivtsi [in Ukraini- 